\title{
The Rhetorical Structure Model Reconstruction of Unaccredited Journal Entries to Become Special Accredited Journal Entries in the Introduction Chapter
}

\author{
Dian Eka Chandra W, Soesetyo, Suhartono, Rian S, and Noermansyah \\ Universitas Bengkulu \\ dian_eka09@yahoo.com
}

\begin{abstract}
This research to reconstructed the rhetorical structure of unaccredited Indonesian Journal Entries (AJP) to become the accredited Indonesian Journal Entries. The research method was developed method with three-phase activities. The data were in the form of written utterance of AJP. The data collection was conducted by examining the introduction chapter of texts or discourses from 50 articles of unaccredited AJP and 80 articles of accredited AJP. The data analysis uses the Delphi technique and the intersubjectivity test. The findings have been based on the panelist reliability test, so it is concluded that the model is consistent (can be trusted). In addition, the model reliability test was also conducted so the model is reliable. The conclusion is the writing of the introduction chapter of AJP (journal entries) in the field of language and literature published in Language \& Arts journals has already used all four phases in the pattern of the Problem Justifying Project (PJP). This is represented by one or several steps in each article introduction part studied with various rhetorical patterns. A different condition appears in the data of the writers in BISA journals; in average it shows a fewer number of steps than the total number of those that have to be used ideally. Recommendations, the writers of unaccredited journals should learn from the writers of accredited journals, so that the compilation of the journals at the study programs and the libraries of faculties and universities will acquire maximum attention
\end{abstract}

Keywords-reconstruction, Indonesian Journal Entries (AJP), development research.

\section{INTRODUCTION}

The text rhetorical reconstruction of the journal entry (next; AJP) introduction part on research using Indonesian language based on student theses at FKIP Unib is important to be conducted because in around ninety percent (90\%) of the theses of student research from February 2008 to September 2013 the phenomenon of writing the introduction part not suitable with the expected writing organization has been discovered. The early data already analyzed by Hermen, Wuri, Sasih, Nainggolan (2015), show that the writers often say that their topics or research problems are necessary or interesting to be researched. It means that most of the Indonesian AJP writers do not justify their research activities argumentatively so that they have not really convinced their readers, unlike the introduction chapter of the English AJP.

This adds to the fact that the student capability in writing academic papers, particularly in writing the introduction chapter, has not fulfilled the requirements and the criteria of a good academic paper. This condition worsens with the results of the interview conducted by the author AJB BISA that all respondents (purposive samples) stated that when writing an article, they only imitate an article that has been written by their seniors, they do not know if there are certain rules on writing academic articles, they just try to fulfill the requirement to graduate, they have not paid attention to the rhetorical style issues, and they do not have special knowledge that the introduction chapter has to be written by paying attention to certain theories (Hermen, 2015)

In general, the motivation that mostly encourages the Master's degree students majoring in Indonesian Language and Literature of FKIP Unib is always related to finishing the last assignment as a requirement to earn the Master's degree and for promotion. Another obstacle, among others, is that there is no rhetorical style development model with the national accredited journal standard that can be a reference in writing the introduction chapter of a research journal article which specifically becomes a teaching material.

Students tend to only imitate the writing pattern of their seniors, and they do not understand the essence of the argument that should appear in the journal article which fulfills scientific requirements. This is important so that their writing can be categorized as scientific writing equal to the writing in neighboring countries. Based on the phenomenon, the research attempts to find solutions by reconstructing the text rhetoric of the introduction part of the Indonesian research 
journal article in order to accomplish the goals of the Professional Educators and Education Staff at the ASEAN level in 2016. Besides that, the increasing learning process and student learning results, particularly in writing articles with argumentative-thinking model products, such as accredited or international journals, become reality. This is necessary as an indicator that the thinking pattern of writing an undergraduate thesis, a thesis, and a dissertation of FKIP students has followed the international standard, following the universal rules of academic writing, even though there is an emphasis to act locally or write the local content. This condition needs to be strengthened with the research result article products reflecting the world-class thinking (being critical).

This way of thinking needs to be developed and practiced seriously by students because it will give a wide impact. The impact meant here is the article writing, involving a team of teachers teaching and guiding as well as examining at the undergraduate and graduate levels, and the students who are asked to reconstruct the text rhetoric of the introduction part of the Indonesian research journal article based on theses are the students that are studying at the Graduate Program of the Indonesian Language Education at FKIP Unib; those students are Indonesian teachers teaching at junior high schools and Madarasah Tsanawiyah (Islamic Elementary Schools). Therefore, this research topic will have quite a wide impact to influence the civitas academica of Higher Education and the teachers to be able to welcome and to be ready to apply the vision and missions of Higher Education. The issue occurring is that how to reconstruct the text rhetoric of the introduction part of the Indonesian research journal article based on theses?

Finding solutions for the topic is really important because the phenomenon of the language science grows and develops very rapidly and dynamically in accordance with the development of science and knowledge as well as technology in general. Various language studies in medical science, internet, computer science, law, economics, philosophy, logic, terminology of science and technology, and literary appreciation grow very rapidly, and even the seminars with special topics in the development of language science have been conducted, such as the National Seminar of the relation among language, health, and humanities in December 2013, the International Seminar of Mother Tongues and Ancestor Values at Universitas Indonesia in May 2012, the UI National Seminar in December 2010, the Pragmatic Seminar in May 2013, the International Linguistic Annual Conference which had been held up to the $11^{\text {th }}$ year in 2013, the International Language Congress every once in 5 years, and by the year 2013 it had been held for the sixth year, and the MLI Journal that is published annually and in 2013 the journal had been published as the $30^{\text {th }}$ edition, A Discourse (an international accredited journal with ISSN1411-2272 vol 13 no.1 April 2011). It means that there have been many findings from the language experts, and it is sophisticated that the work of the language experts from Indonesia has been known worldwide, but the findings have not been integrated productively and innovatively into education in schools (Suyatno, 2009), and in general Higher Education has not implemented those findings. Moreover, in the scientific Indonesian language teaching in schools, the problem-based learning still has not been based on the linguistic research findings. Therefore, the research with the topic of text construction model development of the introduction part of the Indonesian research journal article based on theses of the Indonesian Language Education Program needs to be formulated as a form of research studies whose findings can be used for the improvement and development of the Indonesian Language learning science and technology in order to achieve Professional Educators and Education Staff. The main activity of the linguistic integration at the graduate program is to increase understanding of the preparation of students for learning linguistics. It means the curriculum becomes the guidance in this program and becomes the guidance in carrying out the teaching-learning activities, and specifically the activity of language classes should involve more language materials and involve a cooperation between teachers and the study program to develop resources of language and literature of all students (Recommendations from BAN PT, 2012, during a visitation to the Graduate Study Program of Indonesian Language Education), so that the quality of language teaching and learning that are productive, innovative, and integrated with ancestor values can be improved in order to produce educator resources that are capable of increasing the Indonesian language education quality, specifically the increase of the student thinking formation and in this occasion it is limited to the field of language and literature. This is supported by result of research in Safnil Arsyad, (2014) saw that Indonesian writers who write in social science and humanities journals have their own rhetorical style of RA introduction which are different from the ones found in English RAs. There are three important findings that can be reported in this study. First, the majority of Indonesian RA introductions have move 1, 2 , and 4. However, only few of them have move 3 (justifying the present research). Second, the majority of Indonesia writer justify their research topic simply by reviewing the present knowledge and research practices and/or indentifying the research problem. Third, in contrast to what is commonly found in English RA introduction, very few Indonesia RA writer attempt to evaluated the word of other in previous relevant studies in order to justify their research project.

\section{METHODS}

This research is designed by using the research and development approach. The products discovered are tried out and validated through research and development so that a tested product can be formulated (Sukmadinata, 2015) Resarch early 
activity was conducted by digging a need analysis towards products that would be produced. The need analysis was formulated by conducting interview (by bringing interview guidelines containing points of questions on the early knowledge of writing the introduction chapter and on the text rhetoric of the introduction part of the research journal article) with respondents. The interview activity started with structured observation (participatory and non-participatory equipped with descriptive field notes and reflective field notes to obtain a picture of the text rhetorical model).

A further step was doing the early analysis activity towards 120 BISA journal articles, and then the analysis was continued towards the articles published in an accredited journal (Language and Arts). Based on the two analysis activities, expert validation was conducted to two professors and two doctors). Then, the experts discussed the analysis results and this was conducted on 24 June 2015, and recommendations were formulated that the model that is appropriate to be followed is the model from the articles published in the articles of Language and Arts (accredited). The further model development step was conducted by using the formula of the Panelist Test (7 experts) with the same material to do the model intersubjectivity test.

The Panelist Test or the expert test was carried out to find out whether the model instruments (tests, observation sheets, or questionnaires) have already fulfilled the quality of content or material in accordance with the expected competence. Besides that, the panelist test was used to see the consistency of the measurement tools or instruments towards the assessment of several experts. If the assessment results of several experts show no different results, it means the tests or instruments made can be trusted or are consistent, so that the tests are proper to be used to obtain data. If the assessment results between one expert and another are different, then the instruments are not reliable or cannot be trusted, so that the instruments need to be revised and re-tested.

The formula used to test the similarity of the assessment results of several experts is the internal consistency coefficient or trust coefficient with the symbol of 111 , and the try-out test towards 30 respondents.

The model try-out was carried out to see whether the instruments we made were already suitable or already appropriate to be responded by the research subjects. The try-out for the test was carried out to at least see whether the points of the tests already fulfilled (a) the difficulty level, (b) validity, (c) different styles, (d) reliability, and (e) the distractor function. The try-out of non-test materials (observation sheets, checking lists, and questionnaires) was carried out to see whether the points of instruments already fulfilled (a) validity and (b) reliability.

The try-out of tests was formulated by making questions towards the research topic. The question material was represented in two categories, multiple choice questions and essay questions. The answer sheets that were already filled in by the respondents were collected, graded, and calculated for their validity and reliability. The Development Model with the Delphi technique was concluded by using the inter-subjectivity conclusion principles. The panelist reliability test results were obtained with the score of 0.7441 bigger than 0.70 , so it is concluded that the model is consistent (can be trusted). Besides that, the model reliability test was also conducted, and the result is the value of $\mathrm{r} 11=0.874$ bigger than 0.70 , so the model is reliable.

\section{FINDING AND DISCUSSION}

The research findings reconstruct the findings of Safnil (2014) which described that the introduction chapter of the Indonesian AJP ideally has the acceptable style in English so that the chance for the papers to be published in an international journal will be bigger. The style refers to the model that creates research space or CARS from Swales (1990), Safnil (2014), Murti (2014), Agung (2014), and Wardhna (2014). In general, all phases (following the same standard for the knowledge background, justifying a research topic, justifying research activities, and announcing research activities) were conducted by the writers in both journals either the unaccredited one or the accredited one with the quantification calculation which is in average the same, that is around 10 per cent.

However, in using the steps reflecting the writer thinking activity or reflectivity, there are differences in every step. This reconstruction activity started with the AJP BISA rhetorical analysis conducted by Nainggolan (2015), specifically in the field of language and literary studies (Hermen W. H., 2015). The findings meant can be read in Table 1 with the AJP 120 data. 
Table 1: Recapitulation of Phase I Analysis Results (following the same standard for the background) in the AJP BISA Steps and Language \& Arts (field of Language and Literature)

\begin{tabular}{llcc}
\hline No & Phase/Step & \multicolumn{2}{c}{ Percentage of Using Step } \\
\cline { 3 - 4 } & & BISA & Language \& Arts \\
\hline 1. & Defining important terms & 60 & 30 \\
\hline 2. & Referring to the government policies & 20 & 30 \\
\hline 3. & Explaining short history in the field of research & 60 & 45 \\
\hline 4. & Describing the research geographic location & 30 & 0 \\
\hline 5. & Making general claims & 40 & 40 \\
\hline & N=50 & & \\
\hline
\end{tabular}

Table 1 shows that in reconstruction particularly to follow the same standard of writing the background, the writers of AJB BISA use five steps, which are the step to define important terms (1A), the step to refer to the government policies (1B), the step to explain short history in the field of research (1C), the step to describe the research geographic location (1D), and the step to make general claims (1E). Out of those five steps, there are two steps, $1 \mathrm{~A}$ and $1 \mathrm{C}$, with the same percentage, $60 \%$. It means that there are $60 \%$ out of 10 articles researched using these two steps. Meanwhile, the other steps have their percentage as follows: 1E 40\%, 1D $30 \%$, and 1B 20\% for BISA journals. However, this condition is different for Language and Arts journals. Out of those five steps, there are two steps, $1 \mathrm{~A}$ and $1 \mathrm{~B}$, with the same percentage $30 \%$. It means that there are $30 \%$ out of 10 articles researched using these two steps. Meanwhile, the other steps have their percentage as follows: 1C 45\%, 1D $0 \%$, and 1E $40 \%$.

These phenomena mean that the writers of AJP in both journals have already applied the five steps when writing the background using the same standard. The step is the main step required in the writing of academic articles (Saukah, Ali and Wulyadi, 2006). However, the writers of AJP in the accredited journal do not pay attention to the research location writing step. This happens because the writers think more of the argumentation in the field of science in their studies or research. This fact occurs because writing the introduction chapter is very difficult, and it requires quite significant argumentation so that the writing can be acceptable. In addition, this phase is an important step to have the same perception between writers and readers.

Steps in Phase 1 (Explaining the Research Fields)

This second phase consists of three steps, the step to introduce a research topic (2A), the step to identify research problems (2B), and the last step to review relevant literature review (2C). The percentage of using those steps in the AJP introduction part in the field of literature and language in both journals can be read in the following table.

Table 2: Recapitulation of Phase 2 Analysis Results (explaining research fields) in the AJP BISA Steps and Language \& Arts (Field of Language and Literature)

\begin{tabular}{llcc}
\hline No & \multirow{2}{*}{ Phase/Step } & \multicolumn{2}{c}{ Percentage of Using Step } \\
\cline { 3 - 4 } & & BISA & Language \& Arts \\
\hline 1. & Introducing a research topic & 70 & 85 \\
2. & Identifying research problems & 80 & 13 \\
3. & Reviewing relevant literature review & 80 & 16 \\
& $\mathrm{~N}=120$ AJP & & \\
\hline
\end{tabular}

Table 2 describes that the $2 \mathrm{~B}$ step has the same high percentage as the $2 \mathrm{C}$ step with $80 \%$, while the $2 \mathrm{~A}$ step (discussing the introduction of the research topic) has the percentage of $70 \%$. Furthermore, the step to review relevant literature review has the percentage of $80 \%$. A different condition is found in the journal of language \& arts that the introduction of a research topic has $85 \%$, identifying research problems has $13 \%$, and reviewing relevant literature review has $16 \%$. The phenomena mean that the writers of BISA journals still very much depend on the existence of the relevant literature review. This can be understood because the writers of BISA journals are students related to a study program and their writing is part of their graduation requirements. On the contrary, the writers of the Language and Arts journals are the professional writers in their field of science, so that they are not bound to review relevant literature or to identify research problems. However, the activity to introduce a research topic is very dominant in the step of justifying a research topic. 


\section{Steps in Phase 3 (Justifying Research Activities)}

The step to justify research activities is a very important step because the writers have early data that can strengthen certain reasons on the choice of research activities to be conducted. This phase consists of four steps (showing inconsistency of the previous research results, stating that those problems have not been studied, stating that the topic is important to be studied, and stating that they are interested to research the problems). The condition of using every step of the BISA and Language \& Arts journal writers is different. The condition in detail can be seen in the table below:

Table 3: Recapitulation of Phase 3 Analysis Results (justifying research activities) in the AJP BISA Steps and Language \& Arts (the Field of Language and Literature)

\begin{tabular}{llcc}
\hline No & Phase/Step & \multicolumn{2}{c}{ Percentage of Using Step } \\
\cline { 3 - 4 } & & BISA & Language \& Arts \\
\hline 1. & showing the inconsistency of the previous results & $40 \%$ & 25 \\
2. & stating that the problems have never been studied & $40 \%$ & 0 \\
3. & stating that the topics are important to be studied & $60 \%$ & 0 \\
4. & stating that they are interested to study those & $40 \%$ & 5 \\
& problems & & \\
$\quad \mathrm{N}=50$ AJP & & \\
\hline
\end{tabular}

For the four steps in this phase 3, the BISA journal writers really pay attention to the steps in this phase around $40 \%$, and the step stating that the topics are important to be studied earns $60 \%$. A different condition occurs in the accredited journal writers. There are two steps that are not used at all, and those are step 3A and step 3C. These two steps are not done by the writers because there is a phenomenon that these two steps show that the argumentation cannot be well supported. It means when a writer uses these two steps, the data and facts used to strengthen arguments in this phase 3 are no longer needed. Hence, the Language \& Arts journal writers do not use these two steps $(0 \%)$. However, the step that shows inconsistency of the previous research results is still used because this step shows quite strong argumentation power of the writers $(25 \%)$. It means the accredited journal writers really emphasize on the importance of argumentation when using phases and steps in writing the introduction chapter.

\section{Steps in Phase 4 (Announcing Research Activities)}

The step to announce the research activities is a very important step, as this phase becomes the main argumentation material of the writers to announce their research activities. The steps in this phase consist of 6 steps. Those six steps are (1) explaining the research objectives, (2) stating research questions, (3) describing the special characteristics of research, (4) stating the benefits of research, (5) announcing research findings, and (6) stating research hypotheses. The use of these six steps in this phase is different between the BISA journal writers and the Language \& Arts journal writers. The elaboration of the use of the steps in phase 4 in both the writers of BISA journals and the writers of Language \& Arts journal writers can be read in the table below.

Table 4 : Recapitulation of Phase 4 Analysis Results (announcing research activities (Hermen, 2015) in the AJP BISA Steps and Language \& Arts (Field of Language and Literature)

\begin{tabular}{clcc}
\hline No & Phase/Step & \multicolumn{2}{c}{ Percentage of Using Step } \\
\cline { 3 - 4 } & & $60 \%$ & Language \& Arts \\
\hline 1. & Explaining research objectives & $50 \%$ & $14 \%$ \\
2. & Stating research questions & $40 \%$ & $11 \%$ \\
3. & Describing the special characteristics of & & $15 \%$ \\
& research & $50 \%$ & \\
4. & Stating research benefits & $40 \%$ & $20 \%$ \\
5 & Stating research findings & $50 \%$ & $30 \%$ \\
6 & Stating research hypotheses & & $0 \%$ \\
& N=50 AJP & & \\
\hline
\end{tabular}

In Table 4, we can see that both writers of the BISA journals and of the accredited journals use all steps and phases, although with different percentage. However, the step to state research hypotheses in accredited journals in the field of language and literature research is not used. It means that in the field of language and literature, the step to make research hypotheses is not needed. 


\section{CONCLUSION AND RECOMMENDATIONS}

The writing of the introduction chapter of AJP (journal entries) in the field of language and literature published in Language \& Arts journals has already used all four phases in the pattern of the Problem Justifying Project (PJP). This is represented by one or several steps in each article introduction part studied with various rhetorical patterns. For instance, there are data using 4 phases and 7 steps, and those are steps $1 \mathrm{C}, 2 \mathrm{~A}, 2 \mathrm{~B}, 2 \mathrm{C}, 3 \mathrm{C}, 4 \mathrm{~A}$, and $4 \mathrm{D}$ (around 55\%). The four phases and 19 steps in the theory are connected with the word and/or, so that not all steps in each phase have to be used by writers.

A different condition appears in the data of the writers in BISA journals; in average it shows a fewer number of steps than the total number of those that have to be used ideally. The steps that tend to be used the most frequently are the steps $2 \mathrm{~A}, 2 \mathrm{~B}, 3 \mathrm{D}$, and $4 \mathrm{~A}$ and $1 \mathrm{D}, 3 \mathrm{~A}$, and $4 \mathrm{E}$. This shows that the rhetorical structure patterns of the BISA journal AJP introduction part are not really various, so that this information has to be disseminated so that writers pay attention to the existence of the steps in every phase when writing the introduction part.

The writers of unaccredited journals should learn from the writers of accredited journals, so that the compilation of the journals at the study programs and the libraries of faculties and universities will acquire maximum attention. This needs to be noticed because texts in accredited journals can form the thinking pattern of students

\section{References}

Agung. (2014). Analisis Struktur Retorika Bab Pendahuluan Bidang Kesehatan (Unpublished Thesis). Universitas Bengkulu.

Hermen, S. W. (2015). Kecenderungan Mahasiswa Dalam Menulis Bab Pendahuluan (Unpublished Thesis). Universitas Bengkulu.

Hermen, S. Y. (2015). Kecenderungan Model Konstruksi Retorika Dalam Bab Pendahuluan (Unpublished Thesis). Universitas Bengkulu.

Hermen, W. H. (2015). Kecenderungan Model Retorika Bab Pendahuluan Mahasaiswa Program Pasca Sarjana Pendidikan Bahasa INdonesia FKIP Unib (Unpublished Thesis). Universitas Bengkulu.

Murti, S. (2014). Analisis Struktur Retorika Bab Pendahuluan Bidang Kedokteran (Unpublished Thesis). Universitas Bengkulu.

Nainggolan, H. A. (2015). Analisis Retorika Bab Pendahuluan Tesis Mahasiswa Program Pasca sarjana Pendidikan Bahasa Indonesia FKIP UNIB. (Unpublished Thesis). Universitas Bengkulu.

Safnil. (2014). Menulis Artikel Jurnal Internasional Dengan Gaya Retorika Bahasa Inggris. Bengkulu: FKIP Unib Press. . (2014b). Menulis Artikel Jurnal Internasional Dengan Gaya Retorika Bahasa Inggris. Bengkulu: FKIP Unib Press.

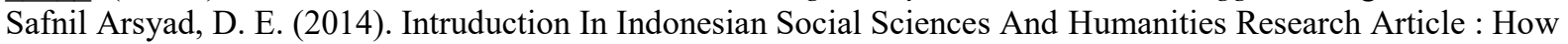
Indonesian Writers Justify Their Research Projects. Linguistik Indonesia, 149-163.

Sukmadinata. (2015). Penelitian-penelitian pengembangan di Indonesia. Bandung: Remaja Rosda Karya Suyatno. (2009). Kompetensi Guru Dalam Menulis Artikel. Pertemuan Pimpinan Pasca 2009 (p. 3). Yogyakarta. Swales. (1990). Genre Analyses: English in Academic and Research Settings. Cambride: Cambridge University Press.

Wardhna, D. E. (2014). Pengembangan Model konstruksi retorika Teks Artikel Jurnal Penelitian Berbahasa Indonesia Berbasis Thesis Mahasiswa Program Pascasarjana Pendidikan Bahasa Indonesia Tahun Ajaran 2015-2016. Bengkulu: A Research Report. 